\title{
LEADERSHIP VALUES - THE PERSPECTIVE OF POTENTIAL MANAGERS FROM POLAND AND UKRAINE
}

\author{
Joanna Szydło ${ }^{1}$, Urszula Widelska ${ }^{2}$ \\ Faculty of Engineering Management, Bialystok University of Technology, \\ Wiejska 45 Street, Bialystok, Poland \\ E-mails: ${ }^{1}$ j.szydlo@pb.edu.pl; ${ }^{2}$ u.widelska@pb.edu.pl (corresponding author)
}

\begin{abstract}
In social sciences, values are perceived as constructs helpful in understanding human attitudes, views, norms and behaviors. Leadership is still current and deeply explored research problem in the science of nowadays management. The aim of the paper is to identify leadership values, using the perspective of potential managers from Poland and Ukraine. Additionally, the aim of it is to systematize knowledge concerned leadership values treated as an important category functioning in management sciences. It seems to be necessary to underline that the notion of values is used by representatives of many sciences. The conclusions are supported by the results of quantitative research conducted among future managers from Poland and Ukraine. In the questionnaire, the Rokeach Value Survey (RVS) was used.
\end{abstract}

Keywords: leadership, values, comparative analysis.

JEL Classification: Z1, Z13.

\section{Introduction}

The notion of values is used by representatives of many sciences. In social sciences they are perceived as constructs which are helpful to the understanding of human attitudes, opinions, norms and behaviours. Values are most often interpreted as abstractive concepts or convictions (cognitive structures) which refer to desired aims (states) or actions. They are arranged according to their importance and transcendent in relation to the situation (they transpire particular situations). They direct assessment or selection of behavior. In the event of conflicting values the person has a tendency to behave according to that value which occupies the higher position in the hierarchy (Rokeach, 1973). Values provide standards for the selection of behaviours. People may justify their actions by invoking both characteristics as well as values but the evaluative component is held solely by values and, for that reason, they are utilized to assess and justify our behaviour and that of others (Schwartz, 1992; Hitlin \& Piliavin, 2004).

The first significant publication which initiated research into values was an article written by Allport and Vernon in 1931. In the 50's of theprevious century Gordon W. Allport (Higgs, 2010) showed that values preferred by an individual are seen as powerful in the sense that they direct the actions of that individual with the aim of fulfilling his needs and that priorities in the area of values impact the perception of reality. In later works the key role of values in giving meaning to specific actions was emphasized by Milton Rokeach (1973) and Shalom H. Schwartz (1992) and this type of approach is still commonly supported in literature (Rohan, 2000; Feldman, 2008).

If values are granted such an important role in the perception of the world and determining human behaviour than the search for the answer to the question which values determine leadership behaviours becomes significant. That which the individual considers to be relevant within his system of values is the result of his choices. These choices are in turn conditioned by geographic, climactic, political, economic, historical and legal variables. They depend on cultural, institutional and personality factors (Rokeach, 1973; Vauclair, Hanke, Fischer, \& Fontaine, 2011; Ariail, Abdolmohammadi, \& Smith, 2012; Mailk \& Yusof, 2013; Titov, 2015; Olsen, 2015; Tuulik, Ounapuu, Kuimet, \& Titov, 2016; Hopkins \& Scott, 2016; Dabic, Potocan, \& Nedelko, 2017). The article focused on cultural factors. The aim is the identification of cultural factors as determinants of the concept of leadership based on values. Research was carried out among potential managers (leaders) from Poland and the Ukraine. Within the presented study value preferences were defined using 
the ranking requiring version of the Rokeach Value Survey (RVS) (Brzozowski, 1989).

\section{Leadership and values}

Leadership is a process by which a person influences other to accomplish an objective and directs the organization in a way that makes it more cohesive and coherent. It is a process whereby an individual influences a group of individuals to achieve a common goal (Sharma \& Jain, 2013). In management science leadership is one of the most often explored research subject which is confirmed, for example, by the number of attempts to define this phenomenon (over 128,000,000 internet results) (Eklund, Barry, \& Grunberg, 2017). In all probability the popularity of this issue is the result of numerous reasons but its multiplicity and complexity seem to be extremely important since leadership concerns the person of the leader - his personality traits as well as his relational skills. Leadership as a research concept continually enters new areas of management science including that of management culture or relational management. The scientific popularity of leadership most likely is utilitarian in nature since a leader not only directly impacts the enterprise and decides about its success as an organization but also influences its market success. The responsibility of a leader is, therefore, undeniable and the systematic progress of scientific exploration in regard to seeking sources of various determinants of the impact a leader has on people and the organization as a system is not surprising since the immense and direct responsibility for the development of numerous spheres of the organization for which he is liable falls onto his shoulders. In referring to the current, very abundant scientific achievement in the area of leadership the most exhibited and still expanded issues, oscillating mainly around theories of leaders and styles of management, must be addressed. In dealing with the theory of leadership we must focus on the domain of personality where the sources of the leader's predestination to his role within the organization are his inborn and/or acquired abilities (see among others Gibb, 1954; Katrz \& Khan, 1978; Yukl, 1989; Kuc, 2006; Koźmiński \& Piotrowski, 2000). The achievement of the personality theory of leadership allows the assessment of the leader through the prism of his traits which include, among others: intelligence, self-motivation, relatively high desire to achieve, being oriented at the well-being of his subordinates, the ability to solve problems and identify tasks or professional and technical skills.
This is augmented by emotional balance and empathy. Within the personality trend we also notice focusing at characteristics connected with the system of values presented by the leader (see among others Carson, Tesluk, \& Marrone, 2007). This concerns his impeccable standing connected with morality and ethics - observing common values respected by the social majority since the true role of leadership is the management of the organization's values with leadership as a whole being valuable and moral (Gini, 1997). In talking about the personality trend the dilemma of identifying the source of leadership traits must also be mentioned. Scientific debate oscillates around whether they are acquired or inborn which, in the context of attitude toward values adhered to by a leader may be significant (Drucker, 2002). Leadership theory additionally draws from the behavioral and situational approaches. In the situational approach an effective leader can adapt his style and methods of action to actual and constantly changing internal and external conditions while, at the same time, minimizing the impact of his own inborn personality traits (Kuc, 2006). We should also not forget about the behavioral approach according to which leaders are capable of choosing any of the various approaches and where the most effective style characterized by giving most care to people as well as production (service or offer) is considered to be the most effective (see among others, Brzezińska \& Paszkowska-Rogacz, 2009; Koźmiński \& Piotrowski, 2000). The evolution of leadership theory makes the manager not only a leader who is oriented at the good of the team and his people but also a subject of the permanent system of connections within the organization with its external surroundings who impacts the interactions occurring within it, for example, with customers (compare Kooman \& Hilders, 2017; Benson, 2016). The large number of relations within the system additionally shows the plurality and diversity of factors determining the role and position of the leader within it. Values must be considered one of those factors. The role of values is a part of the conception put forth by B. Avolio who claims that an authentic leader is someone who is conscious of his manner of thinking as well as acting and who is perceived as being aware of his own moral perspective, knowledge and virtues as well as of other people (Avolio, Walumbwa, \& Weber, 2009). This means that a leader is oriented at others and his appropriate and effective actions may be the result of his system of values (Moczydłowska, 2015). 
The identification of the relationship between values and leadership is contained within the definition of leadership quality since it is measured using two main criteria: effectiveness and ethics. Good leadership is both ethical as well as effective. In all other cases we are dealing with bad leadership. Some values which are significant in relation to good leadership include: seeking perfection, realization of goals, readiness to accept challenges, responsibility and involvement (Lachowski, 2013). Leadership based on values also means leadership founded on trust (but not gullibility), respect for diversity, and acceptance of changeability, order and hierarchy. A modern leader is a person who has a clear system of values (compare Dżwigoł-Barosz, 2014).

It can be concluded that the perception of leadership is changing. A modern leader is a person who promotes ethics and high moral standards rather than someone who acts only on the basis of power and authority. Leadership starts from understanding and involvement in the essence of values (Urbanek, 2011). A perfect confirmation of this conceptual evolution is seen in family businesses. For them, from the socio-emotional perspective (Berrone, Cruz, Gomez-Mejia, \& Larraza-Kintana, 2010), adherence to values is very important (Venter \& Farrington, 2016).

\section{Research methodology. M. Rokeach Value Survey}

To identify the number of contexts of relations and dependencies which occur between leadership and values within this article the authors focused solely on cultural factors. The study included potential leaders from Poland and the Ukraine who function within differing cultural environments. The main respondents included management students. The results of studying at a university, Polish as well as Ukrainian, also prepare students for holding management positions in the future which justifies our selection. The main reason of undertaking studies in the field of management is the prospect of working as a manager at the middle level too. The staff at each level must focus on improving skills, like exerting influence on others or building authority.

These studies have also allowed to capture the dependencies that exist between national culture and leadership values in relation to people who can perform such functions in the future. It lets to show whether the values chosen by the young generation are the same as the values attributed to the leader.
The research is declarative and allows to formulate hypotheses, not to generalize conclusions becoming from the researches. The results show differences and allow to identify future directions of research in the area of leadership.

M. Rokeach's Value Survey was used to identify the cultural factors as determinants of the concept of leadership based on values. At the foundation of the values theory developed by $M$. Rokeach is the assumption that it is within the nature of man to strive to organize the world of ideas, people and authorities into complete, harmonic relationships. The result of these types of actions is the formulation of a system of beliefs which relates to himself as well as other important people and physical objects. Values occupy a central position in the system of beliefs which determines their broadly understood reputational potential. They are identified with cognitive representations of internal needs and drive selfpresentation, evaluation and judgments regarding the self as well as others. They are used as standards governing processes of conscious and unconscious justifications as well as rationalization of actions, thinking and judgments (Czerniawska, 2010, pp. 39-40).

M. Rokeach describes "a value" as an abstract concept and characterizes it as a central, resistant to modifications conviction that is relatively constant throughout life: "a value is a constant belief that the manner of behaviour or the ultimate goal of existence is personally or socially preferred in relation to alternative ways of behaving or goals of existence" $(1973$, p. 5). It is a general criterion determining preferences thanks to which the subject can relate to reality and his own experiences.

Values are strongly reflected in formulated judgments (Czerniawska, 2010, p. 40). M. Rokeach specifies two types of values: those which define the end-states of existence (terminal) and those which represent manners of behaving (instrumental). Terminal values may be divided into: intrapersonal - focusing on the individual and interpersonal - concentrated on society. Among instrumental values it is possible to identify moral values, concerning interpersonal relations, as well as competence values, being more personal than social in character and connected to self-acceptance. Values are unequivocally understood as that which is desirable. An important element of Rokeach's proposal is the search for a relatively complete catalogue of values. The set of values which people esteem is, according to Rokeach, not numerous. People vary not through different 
sets of values but rather through their priority. In other words, most of us have similar values although their importance differs (Cieciuch, 2013, p. 29). The author placed terminal values and instrumental values on two separate scales. He perceived intuitiveness in distinguishing values but maintained that they are appropriately represented. He believed that the assessment of values initiates certain thought processes dependent on relative perception and not the formulation of absolute categories of isolation. Additionally, Rokeach also ascertained that it is ipsative in character which limits possibilities of statistical analysis but despite that faithfully reflects the manner in which values exist. Measurements are made through a ranking procedure (rank 1 means the highest preference level of a value and 18 the lowest level of preference). A person being tested has to, therefore, chose and give priority to that which is more important over that which is less so.

Final values include: "national security" (protection against assault), "family safety" (care for loved ones), "mature love" (sexual and spiritual closeness), "get life" (prosperity), "wisdom" (mature understanding life), "sense of accomplishment" (making one's own contribution), "self-esteem" (self-esteem), "peace in the world" (world free of war and conflict), "real friendship" (close friendship), "pleasure" (nice feelings, no excessive hurry), "internal balance" (no internal conflicts), "equality" (brotherhood, equal opportunities for all), "happiness" (joy, contentment), "world of beauty" (beauty of nature and art), "social recognition" (respect, admiration), "freedom" (personal independence, freedom of choice), "salvation" (salvation of the soul, eternal life), "life full of impressions" (disgusting, active) (Brzozowski, 1989, p. 104).

In the case of final values, one can talk about intrapersonal values - focusing on the individual, such as: "prosperity", "exciting life", "social recognition", "dignity", "freedom", "prosperous life" and interpersonal values - focusing on society, such as "mature love", "friendship", "wisdom", "equality", "peace in the world".

In turn, instrumental values are: "ambitious" (hard-working, with aspirations), "clean" (neat, neat), "intellectual" (intelligent, thinking), "affectionate" (sensitive, delicate), "logical" (consistent, intelligent)), "Independent" (not subordinate to anyone, independent), "imaginative" (bold, creative), "responsible" (reliable, reliable), "courageous" (defending their beliefs), "controlled" (restrained, balanced), "with wide horizons" (with an open mind), "cheerful" (cheerful, easygoing), "helpful" (helping, helping), "obedient" (fulfilling orders, respectful), "honest" (unable to cheat, honest, truthful), "polite" (kind, polite to others), "gifted" (with high skills), "forgiving" (Brzozowski, 1989, p. 105).

In the case of instrumental values, one can speak about moral values such as: "honest", "helpful", "tolerant", "responsible", "forgiving", "obedient" and competence values such as "intelligent", "ambitious", "brave", "talented". When it comes to terminal values it is possible to talk about intrapersonal values - those focusing on the individual, such as: "prosperity", "an exciting life", "social recognition", "dignity", "freedom" or "comfortable life" as well as interpersonal values concentrated on society, including: "mature love", "friendship", "wisdom", "equality" or "world peace". In relation to instrumental values if is possible to discuss moral values, such as: "honesty", "helpfulness", "tolerance", "responsibility", "forgiveness" and "obedience" as well as competence values including: "intelligence", "ambition", "courage" or "capability".

Cultural determination for the preference of values became the main research problem. Our research hypothesis assumed that national culture is one of the factors differentiating value preference of potential leaders. The authors of the work verified the hypothesis by studying respondents living in Poland and Ukraine. The selection of the study sample was target oriented. Students studying various forms of management at the Faculty of Management of the Bialystok University of Technology and from the Kyiv Polytechnic Institute were selected for the study. Respondents numbered 407 students with 201 coming from Poland and 206 from the Ukraine (Figure 1).

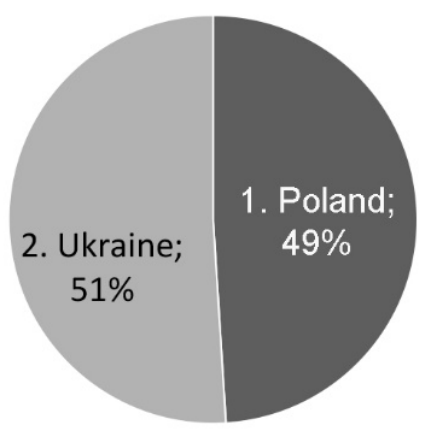

Figure 1. Distribution of respondents in relation to their place of residence (source: developed by the author)

Participants were given a list of terminal values and were instructed to arrange them numerically in accordance to their importance. 


\section{Analysis of research results}

The results were interpreted using the MannWhitney $\mathrm{U}$ test which allowed us to determine whether there are differences between the two groups. During the test the null hypothesis stating that the two sets do not differ is corroborated against the hypothesis which claims that the differences are significant. In the event when $p$ is lower than the accepted cut-off point (for the calculations the cut-off point value for the point of significance was established at 0.05 ) than the null hypothesis is disproven which leads to the conclusion that there are significant differences between the answers given by students from Poland and those from the Ukraine. The results are presented in Table 1.

In eleven cases $p$ is lower than the accepted cut-off point value $(0.05)$ which indicates the presence of statistically significant differences. This concerns terminal values of: "national security" $(p=0.000), \quad$ "family security" $(p=0.000)$, "mature love" $(p=0.000)$, "selfrespect" $(p=0.000)$, "world at peace" $(p=0.000)$, "inner harmony" $(p=0.000)$, "world of beauty" $(p=0.000)$, "an exciting life" $(p=0.000)$, "a comfortable life" $(p=0.000)$, "social recognition" $(p=0.001)$ and "happiness" $(p=0.004)$. Differences occurred also in other variables but were less significant from the statistical point of view. A graphic interpretation of terminal values preferences has been presented in Figure 2.

Both groups considered the value of "family security" to be the most important. With the other values the differences are clear. Respondents from Poland believed values of "mature love", "happiness", "wisdom", "self-respect", "true friendship", "freedom", "inner harmony" and "comfortable life" to be important. They considered: "national security", "pleasure", "a sense of accomplishment", "a world at peace", "equality", "social recognition", "salvation", "an exciting life" and "a world of beauty" as less important. Participants from the Ukraine on the other hand paid great attention to such values as: "wisdom", "national security", "true friendship", "world at peace", "happiness", "mature love" and "freedom". The value of "self respect" made up the middle of the scale. Less significant were: "comfortable life", "an exciting life", "inner harmony", "pleasure", "a sense of accomplishment", "equality", "a world of beauty", "salvation" and "social recognition".

During the second part of the study the respondents received a list of 18 instrumental values.

Table 1. Terminal values preferences of students from Poland and the Ukraine (source: developed by the author)

\begin{tabular}{|l|c|c|c|c|}
\hline \multirow{2}{*}{ Values } & \multicolumn{2}{|c|}{ Arithmetic average of rankings } & \multirow{2}{*}{ Statistic Z } & \multirow{2}{*}{ Level p } \\
\cline { 2 - 3 } & Poland & Ukraine & & 0.000 \\
\hline National security & $10.84(10)$ & $7.26(3)$ & 6.263 & 0.000 \\
\hline Family security & $3.31(1)$ & $4.38(1)$ & -3.494 & 0.000 \\
\hline Mature love & $5.89(2)$ & $7.98(7)$ & -4.722 & 0.001 \\
\hline Comfortable life & $8.7(9)$ & $10.33(10)$ & -3.300 & 0.734 \\
\hline Wisdom & $6.84(4)$ & $6.51(2)$ & 0.340 & 0.400 \\
\hline A sense of accomplishment & $11.05(12)$ & $11.34(14)$ & -0.841 & 0.000 \\
\hline Self-respect & $7.56(5)$ & $9.62(9)$ & -4.878 & 0.000 \\
\hline World at peace & $11.39(13)$ & $7.47(5)$ & 7.220 & 0.171 \\
\hline True friendship & $7.74(6)$ & $7.28(4)$ & 1.368 & 0.820 \\
\hline Pleasure & $10.99(11)$ & $10.81(13)$ & 0.228 & 0.687 \\
\hline Equality & $11.56(14)$ & $11.57(15)$ & -0.403 & 0.000 \\
\hline Inner harmony & $8.67(8)$ & $10.55(12)$ & -4.432 & 0.004 \\
\hline Happiness & $6.66(3)$ & $7.94(6)$ & -2.889 & 0.000 \\
\hline World of beauty & $14.03(18)$ & $12.22(16)$ & 4.960 & 0.001 \\
\hline Social recognition & $12.08(15)$ & $13.19(18)$ & -3.309 & 0.866 \\
\hline Freedom & $8.03(7)$ & $8.2(8)$ & -0.169 & 0.114 \\
\hline Salvation & $12.28(16)$ & $13.18(17)$ & -1.582 & 0.000 \\
\hline An exciting life & $12.77(17)$ & $10.51(11)$ & 4.433 & \\
\hline
\end{tabular}

Z - Mann-Whitney U test. 


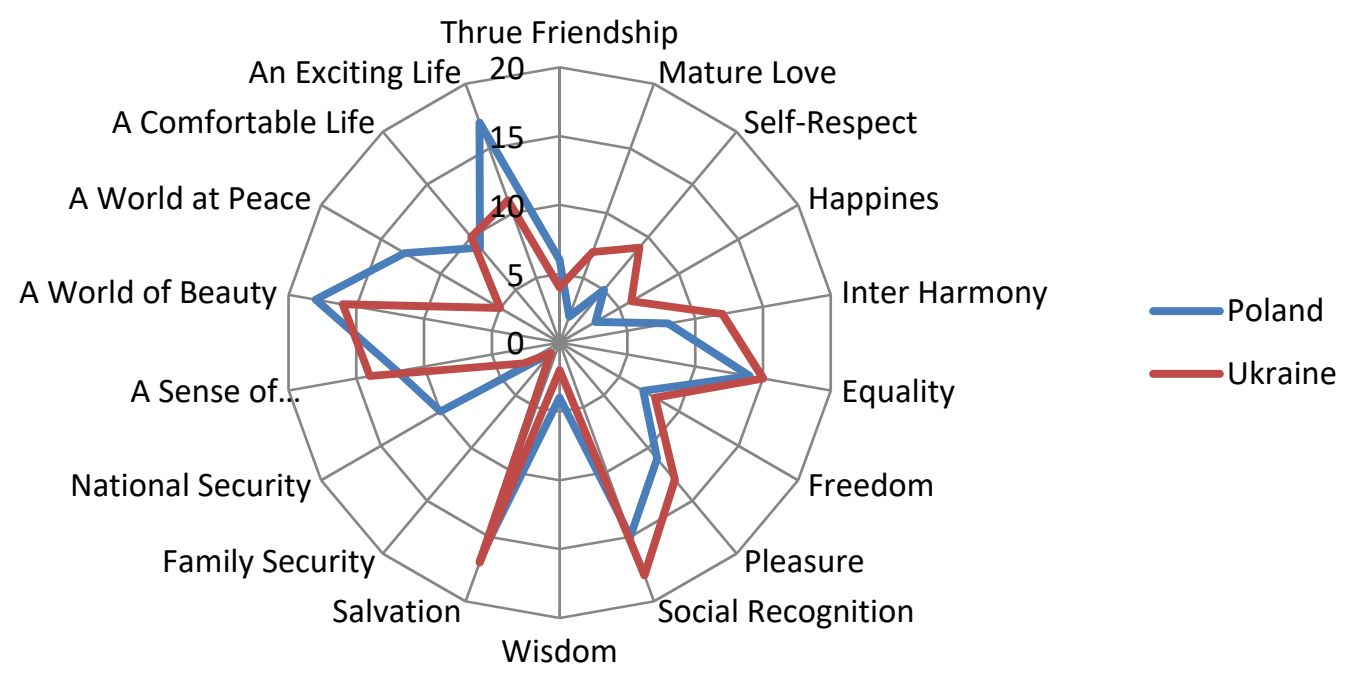

Figure 2. Terminal values preferences of students from Poland and the Ukraine (source: developed by the author)

By numbering them participants showed which values they considered to be important and which they believed to be less significant. The results have been shown in Table 2 .

In regard to nine values $p$ is lower than the cut-off value (0.05) which shows the presence of statistically significant differences. This concerns instrumental values of: "cleanliness" $(p=0.000)$, "intellect" $(p=0.000), " \operatorname{logic} " \quad(p=0.000)$, "responsibility" ( $p=0.000)$, "helpfulness" ( $p=$ $0.000)$, "forgiveness" ( $p=0.001)$, "cheerfulness" $(p=0.005)$, "capability" $(p=0.025)$ and "love" $(p=0.040)$. There were differences in relation to the remaining values but from the statistical point of view they were less significant. A graphic representation of instrumental values has been presented in Figure 3.

Table 2. Instrumental values preferences of students from Poland and the Ukraine (source: developed by the author)

\begin{tabular}{|l|c|c|c|c|}
\hline \multirow{2}{*}{ Values } & \multicolumn{2}{|c|}{ Arithmetic average of rankings } & \multirow{2}{*}{ Statistic Z } & \multirow{2}{*}{ Level p } \\
\cline { 2 - 3 } & Poland & Ukraine & & 0.605 \\
\hline Ambition & $7.91(4)$ & $7.73(5)$ & 0.518 & 0.000 \\
\hline Cleanliness & $10.74(16)$ & $8.32(8)$ & 4.855 & 0.000 \\
\hline Intellect & $9.3(8)$ & $7.5(4)$ & 3.732 & 0.040 \\
\hline Love & $5.7(2)$ & $6.57(1)$ & -2.051 & 0.000 \\
\hline Logic & $9.88(10)$ & $12.43(16)$ & -5.415 & 0.115 \\
\hline Independence & $9.08(6)$ & $8.31(7)$ & 1.574 & 0.591 \\
\hline Broad-Mindedness & $10.3(12)$ & $10.06(12)$ & 0.537 & 0.896 \\
\hline Imagination & $10.63(14)$ & $10.54(14)$ & 0.131 & 0.000 \\
\hline Responsibility & $5.62(1)$ & $7.16(2)$ & -3.830 & 0.499 \\
\hline Courage & $10.01(11)$ & $9.75(11)$ & 0.677 & 0.799 \\
\hline Self-Control & $10.37(13)$ & $10.22(13)$ & 0.255 & 0.005 \\
\hline Cheerfulness & $9.49(9)$ & $8.17(6)$ & 2.787 & 0.000 \\
\hline Helpfulness & $8.3(5)$ & $13.08(17)$ & -9.894 & 0.289 \\
\hline Obedience & $14.07(18)$ & $13.62(18)$ & 1.060 & 0.225 \\
\hline Honesty & $6.65(3)$ & $7.32(3)$ & -1.212 & 0.724 \\
\hline Politeness & $9.26(7)$ & $9.1(9)$ & 0.354 & 0.025 \\
\hline Capability & $10.73(15)$ & $9.55(10)$ & 2.246 & 0.001 \\
\hline Forgiveness & $12.74(17)$ & $11.41(15)$ & 3.315 & \\
\hline Znynn
\end{tabular}

Z - Mann-Whitney U test. 


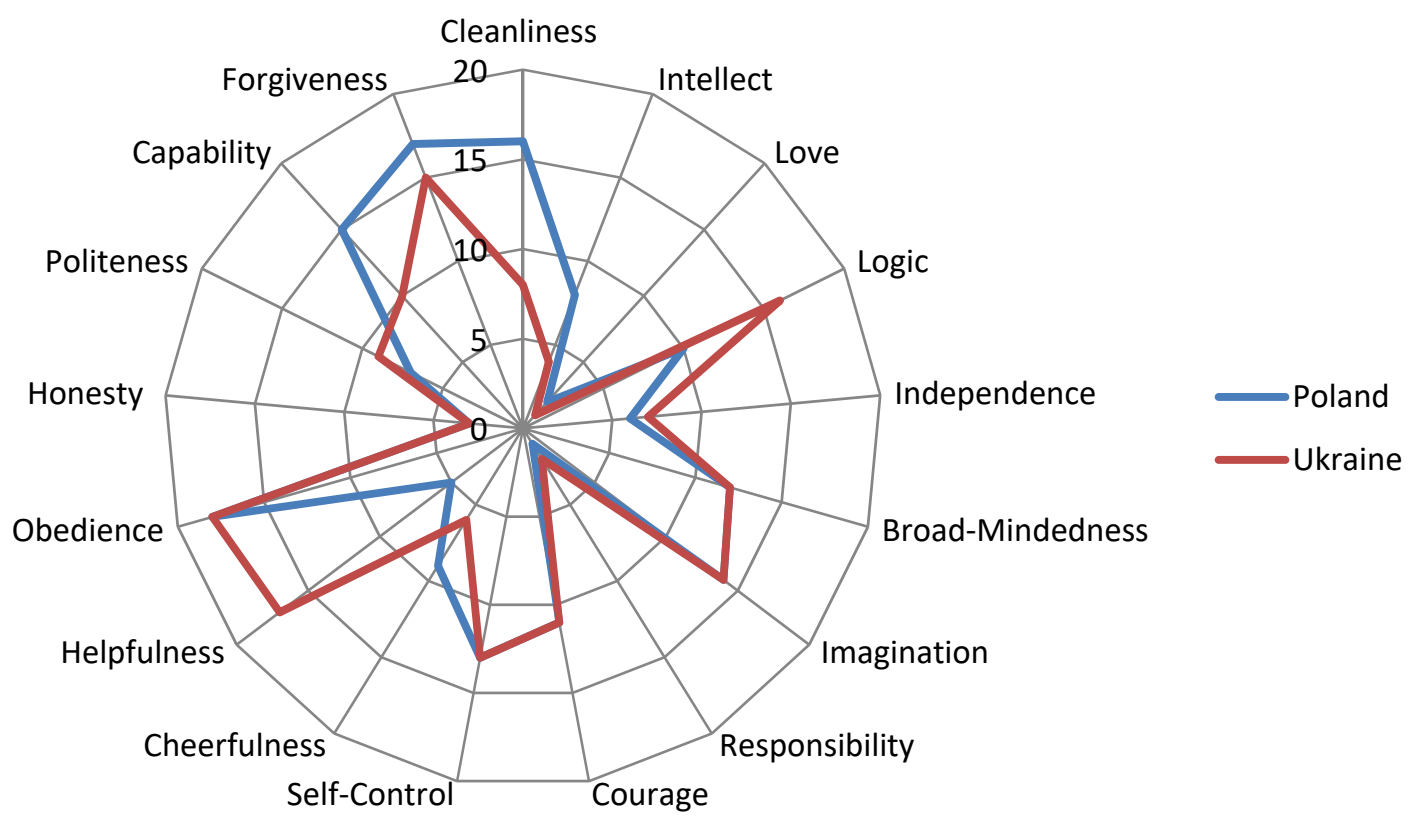

Figure 3. Instrumental values preferences of students from Poland and the Ukraine (source: developed by the author)

In regard to nine values $p$ is lower than the cut-off value $(0.05)$ which shows the presence of statistically significant differences. This concerns instrumental values of: "cleanliness" $(p=0.000)$, "intellect" $(p=0.000), \quad$ logic" $(p=0.000)$, "responsibility" $(p=0.000)$, "helpfulness" $(p=$ $0.000)$, "forgiveness" $(p=0.001)$, "cheerfulness" $(p=0.005)$, "capability" $(p=0.025)$ and "love" $(\mathrm{p}=0.040)$. There were differences in relation to the remaining values but from the statistical point of view they were less significant. A graphic representation of instrumental values has been presented in Figure 3.

Respondents from Poland considered: "responsibility", "love", "honesty" and "helpfulness" to be the most important. Within the center of the scale were: "independence", "politeness", "intellect" and "cheerfulness". "Logic", "courage", "broad-mindedness", "self-control" "imagination", "capability", "cleanliness", "forgiveness" and "obedience" were considered to be less significant. Participants from the Ukraine believed "love", "responsibility", "honesty", "intellect", "ambition", "cheerfulness", "independence" and "cleanliness" to be the most important values. Only "politeness" found its way into the center of the scale. Values which were considered to be less significant included: "capability", "courage", "broad-mindedness", "self-control", "imagination", "forgiveness", "logic", "helpfulness" and "obedience".

\section{Conclusions}

In this article, the identification of dependencies that occur between values and leadership was presented in limited scope. Conclusions seems to be more declarative. The RVS tool was used to select and determine the strength of the influence of factors determining leadership based on values. It should be emphasized that leadership is not only the realization of tasks implemented here and now it is also a set of characteristics and skills specific to the individual. It is why, the inference based on the responses of students, probable leaders in the future seems to be justified. On account of its multiplicity and diversity the concept of leadership based on values requires further systematic exploration. Despite the appearance of numerous definitions, B. R. Kuc (2014, p. 11) acknowledges leadership as one of the poor described issues in social sciences, often misinterpreted, presented only in the form of features. It confirms, leadership is a unique form, one of the skills unheard of and extremely difficult to achieve, and more importantly - without alternatives. The presented structure of answers confirms the role of cultural factors as fundamental for potential leaders. There are, however, differences. These are the result of the particular character of the environment within which respondents function. Students from the Ukraine are more oriented at the external environment. They see the importance of values resulting from the function of the state (such as world peace 
or national security). Students from Poland, on the other hand, focused on internal cultural values including self-respect, freedom or a comfortable life. The order of answers confirms that the concept of leadership based on values does not depend on the leader's personal system of values but rather on that of the environment within which he as well as the organization he leads functions.

When it comes to instrumental values, despite the recorded disparities, differences in their perception by potential leaders from Poland and the Ukraine were smaller. Everyone thought being responsible, honest or ambitious was important. These are, therefore, universal values. Statistically significant differences are not as visible as with terminal values. It must be mentioned that respondents from Poland and the Ukraine chose values focused on relationships and tasks which is an essential condition for being a complete leader in the future.

The hypothesis posed within the study that national culture is one of the factors differentiating preferences regarding values of people within its sphere of influence was confirmed.

\section{References}

Allport, G. W., \& Vernon, P. (1931). A test for personal values. The Journal of Abnormal and Social Psychology, 26(3), 231-248. https://doi.org/10.1037/h0073233

Ariail, D. L., Abdolmohammadi, M. J., \& Smith, L. M. (2012). Ethical predisposition of certified public accountants: A study of gender differences. Research on Professional Responsibility and Ethics in Accounting, 16, 29-56.

https://doi.org/10.1108/S1574-0765(2012)0000016005

Avolio, B., Walumbwa, F., \& Weber, T. J. (2009). Leadership: Current theories, research, and future directions. Annual Review of Psychology, 60, 421-449.

https://doi.org/10.1146/annurev.psych.60.110707.163621

Benson, D. (2016). In pursuit of increased leadership effectiveness. Physician Leadership Journal, September/October, 54-57.

Berrone, P., Cruz, C., Gomez-Mejia, L. R., \& Larraza-Kintana, M. (2010). Socioemotional wealth and corporate responses to institutional pressures: Do family-controlled firms pollute less?', Administrative Science Quarterly, 55(1), 82-113. https://doi.org/10.2189/asqu.2010.55.1.82

Bilsky, W., \& Schwartz, S. H. (1994). Values and personality. European Journal of Personality, 8(3), 163-181. https://doi.org/10.1002/per.2410080303

Brzezińska, E., \& Paszkowska-Rogacz, A. (2009). Człowiek w firmie. Bez obaw i z ochota. Warszawa: Difin.

Brzozowski, P. (1989). Skala Wartości (SW). Polska adaptacja Value Survey M. Rokeacha. Warszawa: Wydział Psychologii Uniwersytetu Warszawskiego.

Carson, J. B., Tesluk, P. E., \& Marrone, J. A. (2007). Shared leadership in teams: An investigation of antecedent conditions and performance. Academy of Management Journal, 50(5), 1217-1234.
Cieciuch, J. (2013). Ksztaltowanie się systemu wartości od dzieciństwa do wczesnej dorostości. Wydawnictwo Liberi Libri.

Czerniawska, M. (2010). Zmiany wartości i postaw młodzieży w okresie przeobrażeń ustrojowych. Kolektywizm versus indywidualizm. Studium interdyscyplinarne. Białystok: Oficyna Wydawnicza Politechniki Białostockiej.

Dabic, M., Potocan, V., \& Nedelko, Z. (2017). Personal values supporting enterprises' innovations in the creative economy. Journal of the Knowledge Economy, 8(4), 1241-1261. https://doi.org/10.1007/s13132-016-0354-z

Drucker, P. (2002). Lider przyszłości. Warszawa: PWN.

Dżwigoł-Barosz, M. (2014). Role liderów biznesu współczesnych przedsiebiorstw. Organizacja i Zarządzanie, z. 70, 105-118.

Eklund, K. E., Barry, E. S., \& Grunberg, N. E. (2017). Gender and Leadership. In A. Alvinius (Ed.), Gender differences in different contexts, 129-150. Retrieved from https://www.intechopen.com/books/references/gender-differences-in-different-contexts/gender-and-leadership

Feather, N. T. (1995). Values, valences, and choice: The influence of values on the perceived attractiveness and choice of alternatives. Journal of Personality and Social Psychology, 68(6), 1135-1151. https://doi.org/10.1037/0022-3514.68.6.1135

Feldman, S. (2008). Wartości, ideologia i strukturalizacja postaw politycznych. In D. O. Sears, L. Huddy, \& R. Jervis (Eds.), Psychologia polityczna. Kraków: Wydawnictwo Uniwersytetu Jagiellońskiego, 435-464.

Gibb, C. A. (1954). Leadership. In G. Lindzey (Ed.), Handbook of social psychology (vol. 2, pp. 877-917).

Gini, A. (1997). Moral leadership: An overview. Journal of Business Ethics, 16(3), 323-330. https://doi.org/10.1023/A:1017959915472

Higgs, M. (2010). Exploring the "Jingle Fallacy": A study of personality and values. Journal of General Management, 36(1), 43-61. https://doi.org/10.1177/030630701003600103

Hitlin, S., \& Piliavin, J. A. (2004). Values: Reviving a dormant concept. Annual Review of Sociology, 30, 359393.

https://doi.org/10.1146/annurev.soc.30.012703.110640

Hopkins, W. E., \& Scott, S. G. (2016). Values-based leadership effectiveness in culturally diverse workplaces. Cross Cultural \& Strategic Management, 23(2), 363385.

Katz, D., \& Kahn, R. L. (1978). The social psychology of organizations $\left(2^{\text {nd }}\right.$ ed.). New York: Wiley.

Koomans, M., \& Hilders, C. (2017). Design-driven leadership for value innovation in healthcare. Design Management Institute, 43-57.

Koźmiński, A., \& Piotrowski, W. (Eds.). (2000). Zarządzanie. Teoria i praktyka. Warszawa: PWN.

Kuc, B. (2006). Od zarządzania do przywództwa. Warszawa: Wydawnictwo Menedżerskie PTM.

Kuc, B. R. (2014). Model przywództwa zintegrowanego. Przedsiębiorstwo Przyszłości, 1(18), 1-27.

Lachowski, S. (2013). Od wartości do działania: przywództwo w czasach przetomowych. Warszawa: Wydawnictwo Studio EMKA.

Mailk, M. N., \& Yusof, S. M. (2013). Inquiry of unique human values: A systematic literature review. Journal of Literature, Languages \& Linguistics, 1, 40-70. 
Moczydłowska, J. M. (2015). The authenticity as the element of organisational leadership. In S. Borkowski, \& R. Stasiak Betlejewska (Eds.), Management aspects in toyotarity. Częstochowa: Oficyna Wydawnicza SMJiP, 19-28.

Olsen, J. E. (2015). Societal values and individual values in reward allocation preferences. Cross Cultural Management, 22(2), 187-200. https://doi.org/10.1108/CCM-09-2013-0130

Rohan, M. J. (2000). A rose by any name? The values construct. Personality and Social Psychology Review, 4(3), 255-277. https://doi.org/10.1207/S15327957PSPR0403_4

Rokeach, M. 1973. The nature of human values. New York: Free Press.

Schwartz, S. H. (1992). Universals in the content and structure of values: Theoretical advances and empirical tests in 20 countries. In M. P. Zanna (Ed.), Advances in experimental social psychology (vol. 25, pp. 1-65). Orlando, FL: Academic Press. https://doi.org/10.1016/S0065-2601(08)60281-6

Sharma, M. K., \& Jain, S. (2013). Leadership management: Principles, models and theories. Global Journal of Management and Business Studies, 3(3), 309-318.

Tice, D. M. (1993). The social motivations of people with low self-esteem. In R. F. Baumeister (Ed.), Self-esteem: The puzzle of low sel-regard (Chapter 3, pp. 3754. New York: Plenum.

https://doi.org/10.1007/978-1-4684-8956-9_3
Titov, E. (2015). Management paradigm values in real and propagated level as prerequisites of organisational success (Unpublished doctoral dissertation). Estonia: Tallinn University of Technology.

Tuulik, K., Ounapuu, T., Kuimet, K., \& Titov, E. (2016). Rokeach's instrumental and terminal values as descriptors of modern organisation values. International Journal of Organizational Leadership, 5, 151-161.

Urbanek, G. (2011). Kompetencje a wartość przedsiębiorstwa: Zasoby niematerialne w nowej gospodarce. Warszawa: Wolters Kluwer, 90-92.

Vauclair, C. M., Hanke, K., Fischer, R., \& Fontaine, J. (2011). The structure of human values at the culture level: A meta-analytical replication of Schwartz's value orientations using the Rokeach Value Survey. Journal of Cross-Cultural Psychology, 42(2), 186-205. https://doi.org/10.1177/0022022110396864

Venter, E., \& Farrington, S. M. (2016). Investigating valueladen leadership styles among family business owners. South African Journal of Business Management, 47(4): 35-46. https://doi.org/10.4102/sajbm.v47i4.73

Yukl, G. A. (1989). Leadership in organizations ( $2^{\text {nd }}$ ed.). Englewood Cliffs, NJ: Prentice Hall. 